\title{
Pricing Climate Risk Mitigation
}

\section{Citation}

Aldy, Joseph E. Pricing Climate Risk Mitigation. Nature Climate Change 5, 396-398 (2015)

\section{Published Version}

doi:10.1038/nclimate2540

\section{Permanent link}

http://nrs.harvard.edu/urn-3:HUL.InstRepos:21150339

\section{Terms of Use}

This article was downloaded from Harvard University's DASH repository, and is made available under the terms and conditions applicable to Other Posted Material, as set forth at http:// nrs.harvard.edu/urn-3:HUL.InstRepos:dash.current.terms-of-use\#LAA

\section{Share Your Story}

The Harvard community has made this article openly available.

Please share how this access benefits you. Submit a story.

\section{Accessibility}




\title{
Pricing climate risk mitigation
}

\author{
Joseph E. Aldy
}

Adaptation and geoengineering responses to climate change should be taken in account when estimating the social cost of carbon.

At the September 2014 UN climate summit, 73 countries and more than 1,000 companies advocated for 'pricing carbon' ${ }^{1}$. Economists have long called for pricing carbon to reflect the social damages associated with the impacts of carbon dioxide emissions on the global climate $^{2,3}$. Such an approach generally reflects the 'polluter pays principle' - as elaborated in the 1992 Rio Declaration on Environment and Development - with its emphasis on the use of economic instruments to internalize environmental costs ${ }^{4}$. Scholars have also called for organizing international negotiations around agreement on a carbon price as the basis for emission commitments ${ }^{5,6}$.

\section{The meaning of carbon pricing}

For some policymakers, setting a price on carbon that reflects the cost of carbon pollution can inform the 'objective' of climate policy. For example, the US Government uses an estimate of the social cost of carbon (SCC) - the present value monetized damages associated with an incremental ton of carbon dioxide emissions - to evaluate fuel economy standards, appliance efficiency standards, and carbon performance standards ${ }^{7}$. Because some laws require regulations to reflect a weighting of benefits and costs, the application of the SCC could determine the ambition of energy and climate policies.

For other policymakers, pricing carbon is an 'instrument' of climate policy - such as carbon dioxide cap-and-trade programs or a carbon tax. For example, the EU Emission Trading Scheme and the British Columbia carbon tax impose a price that carbon dioxide emitters must bear. Of course, these two interpretations can be mutually reinforcing. In a benefit-cost framework, a policy that maximizes net social benefits would equate the social cost of carbon and the price borne by emitters under a tax or cap-and-trade instrument ${ }^{8}$.

Whether the SCC determines the objective of policy, informs the design of a pricing instrument, or serves as a focal point in international negotiations, it will play an important role in the future of climate change policy. The social damages of carbon emissions will depend on the impacts of a warming world, such as sea level rise, extreme weather events, changes in agricultural productivity, as well as potential catastrophic harms, migration and conflict, etc. ${ }^{9}$. The SCC will also vary with alternative efforts to mitigate climate change risks, such as adaptation and geoengineering. Thus, it is important to conceptualize the SCC in the context of the full suite of climate change risk management policies.

\section{Managing risks posed by climate change}


Policymakers, individuals, and businesses can use three general approaches to mitigate the risks posed by climate change. First, they can halt the atmospheric accumulation of greenhouse gases, thereby preventing the problem, through emission abatement. Second, they can avoid some climate change impacts by making investments in adaptation and resilience. Third, they can attempt to 'fix' the problem through geoengineering, such as solar radiation management strategies.

This multi-pronged approach to mitigating climate risk has emerged only recently in the debate over climate change policy. In the 1990s, international and domestic climate change policy focused almost exclusively on emission abatement. In the early 2000s, adaptation joined emission abatement in multilateral negotiations as well as development policy. In recent years, scholars have raised the prospect of geoengineering paired with emission abatement to avoid potentially catastrophic climate change ${ }^{10-12}$. Putting a price on carbon for emission abatement that fails to account for adaptation and geoengineering risks could leave too few resources for adaptation and geoengineering, options with potentially high returns in reducing climate change damages.

\section{Pricing carbon in a world with adaptation and geoengineering}

Pricing carbon within a comprehensive risk management framework requires continued work and advances in our understanding of climate change damages. Scholars from an array of disciplines have raised questions about the damage functions in the integrated assessment models that generate SCC estimates ${ }^{9,13,14}$. Improving the knowledge base on impacts is a necessary foundation for evaluating the risk mitigation impacts of emission abatement, adaptation, and geoengineering.

The status quo integrated assessment model approach produces a SCC without consideration of geoengineering and typically with incomplete or ad hoc attempts to represent adaptation ${ }^{15}$. Of the more than 400,000 SCC estimates produced by the US Government in its 2013 report, 160 scenarios had a SCC in excess of $\$ 1,000$ per ton - or nearly $\$ 10,000$ in annual climate damages per US household for its residential energy consumption. It is difficult to imagine that in such dire states of the world there would be no increase in adaptation investment or geoengineering deployment to offset at least some of these impacts.

Many individuals and businesses have strong incentives to mitigate their exposure to climate change-related risks. If the impacts of climate change become more severe, then they will increase private adaptation investments. Moreover, governments will likely increase outlays for resilience and adaptation if climate risks become more pronounced.

Adaptation will not fully offset the increase in damages, but it likely will offset some climate change risk. As a result, the integrated assessment framework for evaluating the damages of an incremental emission of carbon dioxide should be expanded to include an 'adaptation response function'. Such a function (or system of functions) would represent how adaptation actions by governments and private agents respond to climate change, how adaptation affects the residual damages associated with another ton of carbon dioxide in the air, and how much this adaptation costs. This adaptation response function would result 
in lower monetized damages - because adaptation reduces the impacts of a changing climate - and an opportunity cost for these adaptation investments. If adaptation investments only occur when their returns (benefits of climate risk reduction) exceed their costs, then on net this adaptation function approach would result in a lower SCC than the status quo approach. If private agents, however, make adaptation investments that are privately welfare-improving, but impose local negative externalities (e.g., damming a waterway), then the social costs of carbon could increase when accounting for adaptation response.

Similarly, a 'geoengineering response function' could be incorporated into integrated assessment models. Such a function would likely focus on state behavior and, possibly, multilateral coordination. This response function could represent a future multilateral governance regime, especially if such a regime provided clear guidance on the use of geoengineering. Alternatively, the response function could model the incentives and behavior of various countries likely to react to adverse climate impacts through unilateral geoengineering actions. Just as in the case of adaptation response, a geoengineering response would likely reduce some climate risks (e.g., temperature-related impacts) at the cost of designing and implementing the geoengineering actions. It's important to recognize that these costs would include those associated with launching the geoengineering solution (e.g., injecting reflective particles into the stratosphere) as well as possible unintended side effects. Based on the first-order effects, accounting for geoengineering response would likely reduce the SCC - again through lower impacts net of the direct cost of implementing geoengineering - but the unintended side effects may increase social losses and could potentially offset the social gains from geoengineering.

Constructing such response functions requires, at a minimum, research on three dimensions of the problem. First, greater spatial and temporal resolution in estimating impacts can inform the consideration of adaptation and the incentives for any given state to launch geoengineering. Second, the construction of such response functions should explicitly enable uncertainty analysis. Just as there uncertainties in how emissions translate into impacts, meaningful uncertainties characterize the form, timing, and efficacy of adaptation and geoengineering responses. Third, these functions could inform a richer application of game theory, drawing from international relations and economics, to understand the likely reactions of countries to a changing climate and the prospects for building a credible international climate policy architecture. Since the incentives for freeriding differ dramatically across these three general approaches ${ }^{16}$, explicit modeling of behaviour may be important in constructing the response functions.

\section{Policy implications}

A conventional economic approach to this kind of risk management problem would call for evaluating the returns (say, in reduced damages) associated with incremental investments along each of these three approaches. A policy that maximizes the risk reduction for a given expenditure of resources would equate the marginal return on emission abatement with the marginal return on adaptation with the marginal return on geoengineering. This is simply an extension of the same cost-effectiveness analysis that underlies the case for putting a common price on carbon across all emission sources to maximize emission reductions for a 
given expenditure of resources on abatement. Even if there is no explicit policy effort to equate the marginal returns to actions along these three approaches, the avoided damages associated with emission abatement will likely be affected by adaptation and geoengineering responses that could occur in the future.

The use of a SCC enhances the transparency of public decision-making and can facilitate the identification of opportunities to mitigate climate change risks. The failure to meaningfully slow the growth in global greenhouse gas emissions in recent decades suggests that driving emission abatement through carbon pricing is important, but only part of the risk management portfolio. There will be hard decisions in the future. Policymakers will need rigorous tools that account for all available climate change risk management options to inform these decisions. 
Joseph E. Aldy is at the John F. Kennedy School of Government, Harvard University, 79 J FK Street, Mailbox 57, Cambridge, MA 02138, USA.

email: joseph_aldy@hks.harvard.edu

\section{References}

1. The World Bank. 2014. We support putting a price on carbon. September 21. Internet: http://www.worldbank.org/en/programs/pricing-carbon, last accessed October 20, 2014.

2. Nordhaus, W. D. Am. Econom. Rev. 67, 341-346 (1977).

3. Aldy, J. E., Krupnick, A. J., Newell, R. G., Parry, I. W.H. \& Pizer, W. A. J. Econ. Literat. 48, 903-934 (2010).

4. United Nations. 1992. United Nations Rio Declaration on Environment and Development 1992. Principle 16. Internet:

http://www.unep.org/Documents.Multilingual/Default.asp?DocumentID=78\&Article ID=1163, last accessed October 20, 2014.

5. Cooper, R. N. The case for charges on greenhouse gas emissions in Post-Kyoto International climate policy: Implementing architectures for agreement. (eds Aldy, J. E. \& Stavins, R. N.) (Cambridge University Press, Cambridge, 2010).

6. Weitzman, M. L. J. Assoc, Environ. Resource Economists 1, 29-50 (2014).

7. Interagency Working Group on Social Cost of Carbon (IWGSCC). 2010. Technical Support Document: Social Cost of Carbon for Regulatory Impact Analysis Under Executive Order 12866. Washington, DC: United States Government. Internet: http://www.epa.gov/oms/climate/regulations/scc-tsd.pdf, last accessed October 20, 2014.

8. Nordhaus, W. D. The climate casino: Risk, uncertainty, and economics for a warming world. (Yale University Press, New Haven, 2013).

9. Revesz, R. L. et al. Nature 508, 173-175 (2014).

10. Crutzen, P. J. Climat. Change 77, 211-219 (2006).

11. Wigley, T. M. L. Science 314, 452-454 (2006).

12. Keith, D. A case for climate engineering. (MIT Press, Cambridge, 2013).

13. Pindyck, R. S. J. Econom, Lit. 51, 860-872 (2013).

14. Pizer, W. et al. Science 346, 1189-1190 (2014).

15. Interagency Working Group on Social Cost of Carbon (IWGSCC). 2013. Technical Support Document: Technical Update of the Social Cost of Carbon for Regulatory Impact Analysis Under Executive Order 12866. Washington, DC: United States Government. Internet:

http://www.whitehouse.gov/sites/default/files/omb/inforeg/social cost of carbon for ria 2013 update.pdf, last accessed October 20, 2014.

16. Barrett, S. A multitrack climate treaty system. in Architectures for agreement: Addressing global climate change in the Post-Kyoto world (eds Aldy, J. E. \& Stavins, R. N.) (Cambridge University Press. Cambridge, 2007). 